\title{
Niewydolność serca i powtarzające się hospitalizacje
}

\author{
Heart failure and rehospitalization
}

\author{
Małgorzata Lelonek \\ Klinika Kardiologii Katedry Kardiologii i Kardiochirurgii Uniwersytetu Medycznego w Łodzi
}

\section{Streszczenie}

Postęp leczenia głównie w zakresie elektroterapii spowodował, że pacjenci z niewydolnością serca (HF) obecnie żyją dłużej. Progresja choroby mimo leczenia przechodzi w zaawansowane stadia HF z dominującym obrazem pump failure. Zjawisko to jest związane ze zwiększeniem liczby hospitalizacji z powodu HF. Dlatego konieczne jest wczesne wdrażanie metod terapeutycznych w celu zmniejszenia liczby ponownych hospitalizacji z powodu zaostrzenia HF.

Słowa kluczowe: niewydolność serca, leczenie, powtarzające się hospitalizacje

Folia Cardiologica 2016; 11, 1: 37-46

\section{Wstęp}

Niewydolność serca (HF, heart failure) jest obecnie jednym z najpoważniejszych problemów zdrowotnych Polaków. Szacuje się, że w Polsce na HF choruje około miliona osób, a w najbliższych 25 latach przybędzie kolejne 250 tys. [1]. Na świecie HF jest globalnym problemem zdrowia publicznego dotyczącym aż 23 mln osób. W Stanach Zjednoczonych częstość występowania HF szacuje się na 5,7 mln [2]. Wśród krajów reprezentowanych w Europejskim Towarzystwie Kardiologicznym (ESC, European Society of Cardiology) liczba pacjentów z HF wynosi około $15 \mathrm{mln}$ [3]. Podsumowując, można mówić o epidemii HF.

Mimo postępu kardiologii rokowanie w HF jest nadal poważne. W ciągu 5 lat umiera 60\% mężczyzn i 40\% kobiet. Śmiertelność całej populacji chorych z HF, niezależnie od etiologii, wynosi około 10\% rocznie. Liczba pacjentów z tą chorobą jest 2,5 razy większa niż liczba chorujących na wszystkie nowotwory łącznie (mln chorych z HF v. 400 tys. chorujących na nowotwory). Codziennie 164 Polaków umiera z powodu HF, co oznacza 60 tys. zgonów rocznie [1]. Aż połowa pacjentów umiera w ciągu 5 lat od rozpo- znania choroby. Są to istotnie gorsze dane statystyczne niż w przypadku raka piersi, jajnika czy prostaty. Jakość życia chorych z HF jest podobna jak u pacjentów z przewlekłą chorobą nerek poddawanych dializoterapii 3 razy w tygodniu oraz gorsza niż chorych na wirusowe zapalenie wątroby czy depresję.

\section{Aspekty ekonomiczne hospitalizacji w niewydolności serca}

Roczne koszty leczenia chorych z HF w Polsce zwiększyły się do 1,7 mld zł i stanowią już 3,2 proc. budżetu Narodowego Funduszu Zdrowia [1]. Według danych Instytutu Zarządzania w Ochronie Zdrowia, w 2009 roku wszystkie rozpoznania w ramach HF stanowiły 7,17\% hospitalizacji ogółem wśród kobiet powyżej 65 rż. i 6,77\% w grupie mężczyzn powyżej 65 rż. [1]. W 2012 roku Narodowy Fundusz Zdrowia (NFZ) sfinansował świadczenia dla pacjentów leczonych z powodu HF w wysokości ponad $672 \mathrm{mln}$ zł [1]. Najwięcej wydano na świadczenia szpitalne - $635 \mathrm{mln}$ zł (94\%), następnie rehabilitację leczniczą - $26 \mathrm{mln}$ zł (4\%) oraz ambulatoryjną opiekę specjalistyczną - $10 \mathrm{mln}$ zł (2\%). Udział tych kosztów

Adres do korespondencji: prof. dr hab. n. med. Małgorzata Lelonek, Klinika Kardiologii, Katedra Kardiologii i Kardiochirurgii, Uniwersytet Medyczny, ul. Pomorska 251, 92-213 Łódź, tel. 4220143 18, faks 4220143 11, e-mail: malgorzata.lelonek@umed.lodz.pl 
w całości świadczeń wyniósł 2,2\% w przypadku lecznictwa szpitalnego, 1,3\% w przypadku rehabilitacji oraz $0,2 \%$ w przypadku ambulatoryjnej opieki specjalistycznej [1].

Niewydolność serca jest najczęstszą przyczyną hospitalizacji wśród osób po 65. roku życia. W 2012 roku NFZ rozliczył leczenie tej choroby w grupie 288 tys. pacjentów ogółem, przy czym 158 tys. stanowiły osoby powyżej 69. roku życia [1]. Tryb nagły przyjęcia do szpitala dotyczył prawie 83\% ogólnej liczby przyjęć. W 2012 roku w Polsce 187 tys. chorych przyjęto do szpitala z powodu HF, a co czwarty pacjent był ponownie hospitalizowany w czasie krótszym niż 30 dni od wypisania.

Polska znalazła się na pierwszym miejscu wśród 30 krajów OECD (Organisation for Economic Co-operation and Development) pod względem liczby hospitalizacji z powodu HF [4], wyprzedzając w tym zakresie Stany Zjednoczone, Niemcy i Austrię. Liczba hospitalizacji w naszym kraju 2-krotnie przekracza średnią dla OECD. Co drugi chory z HF jest hospitalizowany przynajmniej raz w roku, co trzeci -2 razy, a co $10-3$ razy [1]. Średni roczny koszt pobytu takiego chorego w szpitalu przekracza 7 tys. zł i prawie 15 razy przewyższa koszty opieki ambulatoryjnej i wizyt lekarskich, które łącznie nie przekraczają 450 zł rocznie. Średni okres hospitalizacji pacjentów z HF (grupa E53; HF u osób > 69 rż. lub z powikłaniami i chorobami współistniejącymi) w 2012 roku w Polsce wynosiła 6 dni (mediana) [1]. Przewiduje się, że przy wzroście liczby chorych z HF o 25\% w ciągu najbliższych 20 lat związane z tym koszty leczenia wzrosną 2-krotnie.

\section{Powtarzające się hospitalizacje z powodu HF w wytycznych ESC}

Przed wprowadzeniem nowoczesnego leczenia śmiertelność 5-letnia w HF wynosiła 60-70\% [3]. W ostatnich latach rokowanie w tej chorobie uległo poprawie, zmieniła się natomiast struktura zgonów. Wzrasta liczba zgonów powodowanych niewydolnością serca jako pompy - pump failure [5]. Postęp leczenia głównie w zakresie elektroterapii spowodował, że pacjenci z HF, kiedyś umierający z powodu nagłego zgonu sercowego, gdy byli w II i III klasie według New York Heart Association (NYHA), obecnie żyją dłużej, a ich choroba postępuje mimo leczenia i przechodzi w zaawansowane stadia HF z dominującym obrazem pump failure. Zjawisko to wiąże się ze zwiększeniem liczby hospitalizacji z powodu HF. Dlatego konieczne jest wczesne wdrażanie metod terapeutycznych poprawiających wydolność serca jako pompy. Warto przypomnieć, że w ostatnich wytycznych European Society of Cardiology (ESC) z 2012 dotyczących leczenia HF [3] po raz pierwszy wyraźnie okreśIono redukcję liczby hospitalizacji jako cel terapeutyczny. Zestawienie najważniejszych badań, w których hospitali- zacje z powodu HF były głównym lub złożonym punktem końcowym, przedstawiono w tabeli 1 [6-15].

Do celów terapeutycznych w HF należą [3]:

- złagodzenie objawów podmiotowych i przedmiotowych:

- poprawa jakości życia,

- zwiększenie wydolności wysiłkowej;

- ograniczenie liczby hospitalizacji;

- poprawa przeżycia.

Zgodnie z aktualnym stanowiskiem ESC każdy wykazujący objawy pacjent z HF w II-IV klasie według NYHA $z$ frakcją wyrzutową (EF, ejection fraction) poniżej $40 \%$ w celu poprawy przeżycia i ograniczenia hospitalizacji

(klasa I, poziom A) powinien być leczony [3]:

- inhibitorem konwertazy angiotensyny (ACE, angiotensin-converting enzyme) lub antagonistą receptora dla angiotensynowego (ARB, angiotensin receptor blocker) w przypadku nietolerancji inhibitorów ACE;

- lekiem beta-adrenolitycznym;

- antagonistą receptora mineralokortykoidowego (MRA, mineralocorticoid receptor antagonist) (kryterium EF $<35 \%$ )

oraz w celu redukcji liczby ponownych hospitalizacji dodatkowo

- iwabradyną, jeśli częstość rytm zatokowego przekracza 70/min (klasa lla, poziom B).

Do podjęcia decyzji terapeutycznych w HF lekarz praktyk potrzebuje następujących informacji:

- stopnia zaawansowania obrazu klinicznego z ustaleniem klasy według NYHA, informacji z badania przedmiotowego (m.in. cechy retencji płynów);

- zapisu spoczynkowego elektrokardiogramu (EKG) z oceną rytmu serca i jego częstości oraz czasu trwania zespołu QRS;

- określenie frakcji wyrzutowej lewej komory (LVEF, left ventricular ejection fraction) w badaniu echokardiograficznym.

Elektroterapia z wykorzystaniem wszczepialnego kardiowertera-defibrylatora (ICD, implantable cardioverter-defibrillator), w celu poprawy przeżycia, czy terapia resynchronizująca (CRT, cardiac resynchronization therapy), w celu poprawy przeżycia i obniżenia ryzyka ponownych hospitalizacji, powinna być stosowana u pacjentów z objawami mimo optymalnej farmakoterapii (inhibitor ACE, beta-adrenolityk, MRA) stosowanej przez co najmniej 3 miesiące, u których występuje trwałe obniżenie LVEF, a oczekiwany czas przeżycia w dobrym stanie funkcjonalnym przekracza rok, z uwzględnieniem zasad zawartych na rycinie 1 [3].

Podstawą leczenia chorych z HF pozostają wytyczne ESC, jednak nadal utrzymuje się dysproporcja między stosowaniem się do zawartych w nich zaleceń a codzienną praktyką [3]. By osiągnąć cele terapeutyczne, należy dążyć do optymalnej według wytycznych terapii farmakologicznej 
Tabela 1. Zestawienie głównych badań dotyczących problemu hospitalizacji w niewydolności serca (HF, heart failure) (źródła [6-15])

\begin{tabular}{|c|c|c|c|c|c|}
\hline Nazwa badania & Rodzaj badania & Cel badania & Kryteria włączenia & Główne punkty końcowe & $\begin{array}{l}\text { Populacja i okres } \\
\text { obserwacji }\end{array}$ \\
\hline OPTIMIZE-HF [6] & Rejestr & $\begin{array}{l}\text { Ocena stosowa- } \\
\text { nia wytycznych } \\
\text { w leczeniu HF, } \\
\text { poprawa opieki } \\
\text { nad chorym z HF }\end{array}$ & $\begin{array}{l}\text { Pacjenci hospitalizo- } \\
\text { wani z rozpoznaniem } \\
\text { HF, wiek > 18. rż., } \\
\text { LVEF > 40\% i < 40\% }\end{array}$ & $\begin{array}{l}\text { Zgon wewnątrzszpitalny; } \\
\text { zgon/rehospitalizacja } \\
\text { w ciagu } 60-90 \text { dni od } \\
\text { wypisania }\end{array}$ & $\begin{array}{l}48612 \text { pacjen- } \\
\text { tów, follow-up po } \\
60-90 \text { dniach od } \\
\text { hospitalizacji }\end{array}$ \\
\hline $\begin{array}{l}\text { ACTIVE in CHF } \\
\text { [7] }\end{array}$ & $\begin{array}{l}\text { Randomizowane, } \\
\text { podwójnie ślepa } \\
\text { próba, kontrolo- } \\
\text { wane placebo }\end{array}$ & $\begin{array}{l}\text { Skuteczność } \\
\text { różnych dawek } \\
\text { tolwaptanu }\end{array}$ & $\begin{array}{l}\text { Pacjenci hospita- } \\
\text { lizowani z powodu } \\
\text { zaostrzenia HF, } \\
\text { wiek > 18. rż., LVEF } \\
<40 \% \text {, III/IV klasa } \\
\text { wg NYHA }\end{array}$ & $\begin{array}{l}\text { Zmniejszenie masy ciała; } \\
\text { redukcja zaostrzenia } \\
\text { CHF (zgon, rehospitali- } \\
\text { zacja, nieplanowa wizyta } \\
\text { spowodowana HF) }\end{array}$ & $\begin{array}{l}319 \text { pacjentów, } \\
\text { follow-up } 60 \mathrm{dni} \\
\text { po randomizacji }\end{array}$ \\
\hline EVEREST [8] & $\begin{array}{l}\text { Randomizowane, } \\
\text { podwójnie ślepa } \\
\text { próba, kontrolo- } \\
\text { wane placebo }\end{array}$ & $\begin{array}{l}\text { Skuteczność tol- } \\
\text { waptanu }\end{array}$ & $\begin{array}{l}\text { Pacjenci hospita- } \\
\text { lizowani z powodu } \\
\text { zaostrzenia HF, wiek } \\
>\text { 18. rż. LVEF < 40\%, } \\
\text { III/IV klasa wg NYHA, } \\
\text { objawy retencji pły- } \\
\text { nów }\end{array}$ & $\begin{array}{l}\text { Zgon z jakiejkolwiek } \\
\text { przyczyny; złożony punkt } \\
\text { końcowy (zgon z przyczyn } \\
\text { sercowo-naczyniowych/ } \\
\text { /rehospitalizacja z powo- } \\
\text { du HF) }\end{array}$ & $\begin{array}{l}4133 \text { pacjentów, } \\
\text { mediana obser- } \\
\text { wacji } 9,9 \text { mie- } \\
\text { siąca }\end{array}$ \\
\hline OPTIME-CHF [9] & $\begin{array}{l}\text { Randomizowane, } \\
\text { podwójnie ślepa } \\
\text { próba, kontrolo- } \\
\text { wane placebo }\end{array}$ & $\begin{array}{l}\text { Skuteczność } \\
\text { milrinonu }\end{array}$ & $\begin{array}{l}\text { Pacjenci hospita- } \\
\text { lizowani z powodu } \\
\text { zaostrzenia HF, wiek } \\
>\text { 18. rż. LVEF < 40\%, }\end{array}$ & $\begin{array}{l}\text { Liczba dni hospitalizacji } \\
\text { w ciągu } 60 \text { dni od rando- } \\
\text { mizacji }\end{array}$ & $\begin{array}{l}951 \text { pacjentów, } \\
\text { follow-up } 30 \\
\text { i } 60 \text { dni po hospi- } \\
\text { talizacji }\end{array}$ \\
\hline ESCAPE [10] & Randomizowane & $\begin{array}{l}\text { Skuteczność } \\
\text { monitorowania } \\
\text { za pomocą cew- } \\
\text { nikowania tętnicy } \\
\text { płucnej }\end{array}$ & $\begin{array}{l}\text { IV klasa wg NYHA, } \\
\text { LVEF }<30 \% \text {, objawy } \\
\text { retencji płynów }\end{array}$ & $\begin{array}{l}\text { Liczba dni hospitalizacji } \\
\text { w ciągu } 6 \text { miesięcy od } \\
\text { randomizacji; śmierć }\end{array}$ & $\begin{array}{l}433 \text { pacjentów, } \\
\text { follow-up po } \\
6 \text { miesiącach }\end{array}$ \\
\hline SHIFT [11] & $\begin{array}{l}\text { Randomizowane, } \\
\text { kontrolowane } \\
\text { placebo }\end{array}$ & $\begin{array}{l}\text { Skuteczność iwa- } \\
\text { bradyny w lecze- } \\
\text { niu HF }\end{array}$ & $\begin{array}{l}\text { II-IV klasa wg NYHA, } \\
\mathrm{EF}<35 \%, \text { rytm } \\
\text { zatokowy }>70 / \mathrm{min}, \\
\text { hospitalizacja } \\
\text { w ciągu ostatnich } \\
12 \text { miesięcy }\end{array}$ & $\begin{array}{l}\text { Zgon z przyczyn sercowo- } \\
\text {-naczyniowych lub hospi- } \\
\text { talizacja z powodu HF }\end{array}$ & $\begin{array}{l}6588 \text { pacjentów, } \\
\text { mediana obser- } \\
\text { wacji } 23 \text { miesiące }\end{array}$ \\
\hline $\begin{array}{l}\text { COMPANION } \\
{[12]}\end{array}$ & $\begin{array}{l}\text { Podwójnie zaśle- } \\
\text { pione, randomizo- } \\
\text { wane }\end{array}$ & $\begin{array}{l}\text { Optymalne lecze- } \\
\text { nie zachowawcze } \\
\text { v. CRT-P lub } \\
\text { v. CRT-D }\end{array}$ & $\begin{array}{l}\text { III-IV klasa wg } \\
\text { NYHA, LVEF < 35\%, } \\
\text { QRS > } 120 \mathrm{~ms}\end{array}$ & $\begin{array}{l}\text { Umieralność całkowita } \\
\text { lub hospitalizacja }\end{array}$ & $\begin{array}{l}1520 \text { pacjentów; } \\
15 \text { miesięcy }\end{array}$ \\
\hline MADIT-CRT [13] & $\begin{array}{l}\text { Pojedynczo zaśle- } \\
\text { pione, randomizo- } \\
\text { wane }\end{array}$ & CRT-D v. ICD & $\begin{array}{l}\text { I-II klasa wg NYHA, } \\
\text { LVEF }<30 \% \text {, } \\
\text { QRS }>130 \text { ms }\end{array}$ & $\begin{array}{l}\text { Śmiertelność całkowita } \\
\text { lub hospitalizacje z po- } \\
\text { wodu HF }\end{array}$ & $\begin{array}{l}1820 \text { pacjentów, } \\
12 \text { miesięcy }\end{array}$ \\
\hline RAFT [14] & $\begin{array}{l}\text { Podwójnie zaśle- } \\
\text { pione, randomizo- } \\
\text { wane }\end{array}$ & CRT-D v. ICD & $\begin{array}{l}\text { II-III klasa wg } \\
\text { NYHA, LVEF < 30\%, } \\
\text { QRS > } 120 \mathrm{~ms}\end{array}$ & $\begin{array}{l}\text { Śmiertelność całkowita } \\
\text { lub hospitalizacje z po- } \\
\text { wodu HF }\end{array}$ & $\begin{array}{l}1798 \text { pacjentów, } \\
40 \text { miesięcy }\end{array}$ \\
\hline PARADIGM [15] & $\begin{array}{l}\text { Podwójnie zaśle- } \\
\text { pione, randomizo- } \\
\text { wane }\end{array}$ & $\begin{array}{l}\text { LCZ696 v. ena- } \\
\text { lapril }\end{array}$ & $\begin{array}{l}\text { II-IV klasa wg NYHA } \\
\text { LVEF < } 40 \%\end{array}$ & $\begin{array}{l}\text { Śmiertelność sercowo- } \\
\text {-naczyniowa lub hospita- } \\
\text { lizacje z powodu HF }\end{array}$ & $\begin{array}{l}8442 \text { pacjentów, } \\
\text { mediana } 27 \text { mie- } \\
\text { sięcy }\end{array}$ \\
\hline
\end{tabular}

OPTIMIZE-HF - Organized Program To Initiate Lifesaving Treatment In Hospitalized Patients With Heart Failure; LVEF (left ventricular ejection fraction) - frakcja wyrzutowa lewej komory; ACTIVE in CHF Acute and Chronic Therapeutic Impact of a Vasopressin Antagonist in Chronic Heart Failure; NYHA - New York Heart Association; CHF (chronic feart failure) - przewlekła niewydolność serca; EVEREST - Efficacy of Vasopressin Antagonism in Heart Failure Outcome Study with Tolvaptan; OPTIME CHF - Outcomes of a Prospective Trial of Intravenous Milrinone for Exacerbations of Chronic Heart Failure; EF (ejection fraction) - frakcja wyrzutowa; COMPANION - Comparison of Medical Therapy, Pacing, and Defibrillation in Heart Failure; CRT-P (cardiac resynchronization therapy with pacemaker with function) - terapia resynchronizująca z funkcją stymulacji; CRT-D (cardiac resynchronization therapy with defibrillator function) - terapia resynchronizująca z funkcją defibrylacji; ICD (implantable cardioverter-defibrillator) - wszczepialny kardiowerter-defibrylator; MADIT-CRT - Multicenter Automatic Defibrillator Implantation Trial with Cardiac Resynchronization Therapy; RAFT - Resynchronization-Defibrillation for Ambulatory Heart Failure Trial; PARADIGM - Prospective comparison of ARNI with angiotensin convering-enzyme inhibitors to determine impact on global mortality and morbidity 


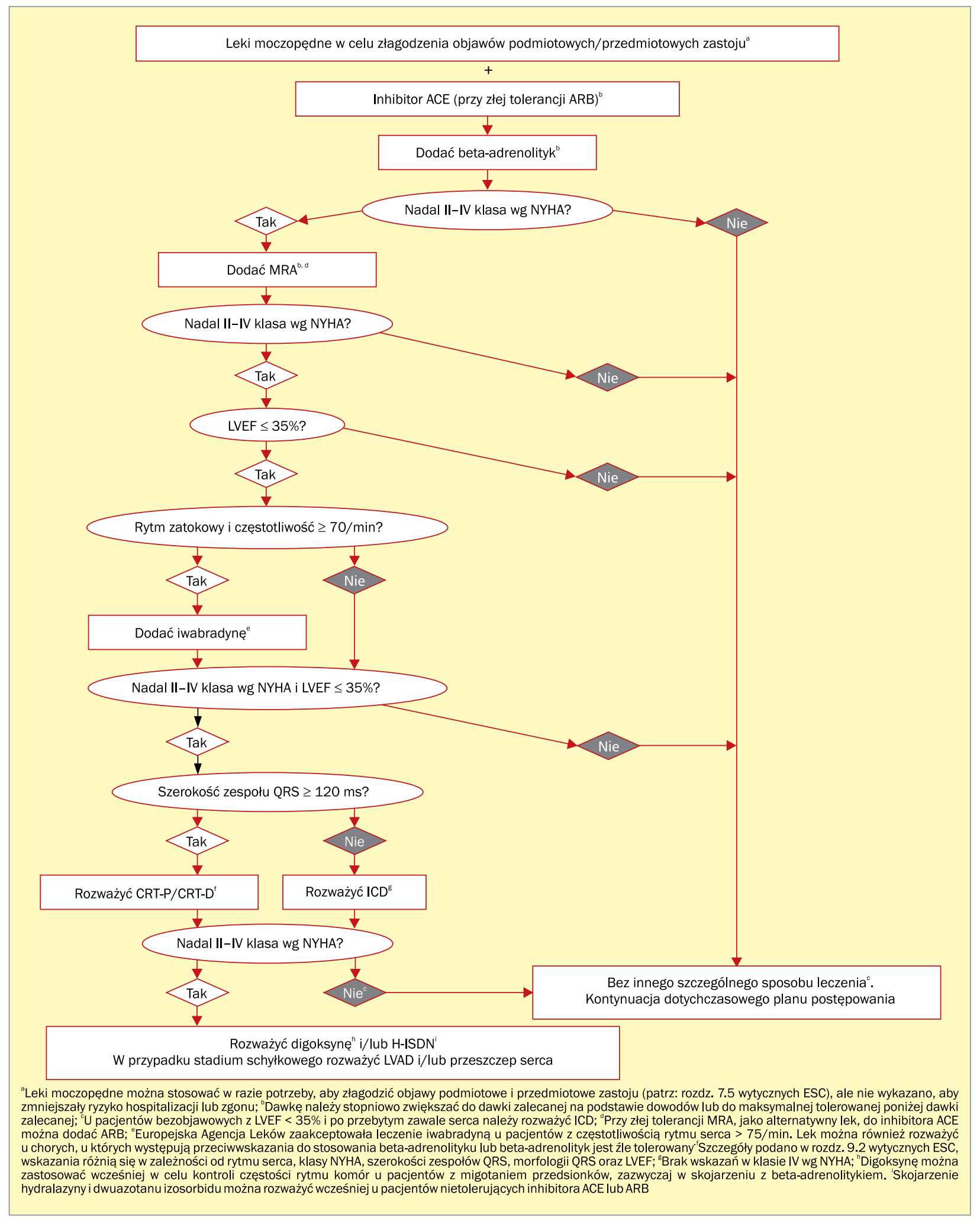

Rycina 1. Schemat postępowania terapeutycznego w przewlekłej niewydolności serca (na podstawie [3]); ACE (angiotensin-converting enzyme) - enzym konwertujący angiotensynę; ARB (angiotensin receptor blocker) - antagonista receptora angiotensynowego; NYHA - New York Heart Association; MRA (mineralocorticoid receptor antagonist) - antagonista receptora mineralokartykoidowego; LVEF (left ventricular ejection fraction) - frakcja wyrzutowa lewej komory; CRT-P (cardiac resynchronization therapy with pacemaker with function) - terapia resynchronizująca z funkcją stymulacji; CRT-D (cardiac resynchronization therapy with defibrillator function) - terapia resynchronizująca z funkcją defibrylacji; ICD (implantable cardioverter-defibrillator) - wszczepialny kardiowerter-defibrylator; H-ISDN (hydralazine and isosorbide dinitrate) - hydralazyna i diazotan izosorbidu; LVAD (left ventricular assist device) - urządzenie wspomagające lewą komore 
i elektroterapii oraz rewaskularyzacji u pacjentów z chorobą wieńcową.

\section{Hospitalizacje w HF a rokowanie}

Rejestry i badania przeprowadzone w ostatnich latach wskazują, że przebieg kliniczny i rokowanie znacznie się różnią w populacjach pacjentów ambulatoryjnych z HF oraz chorych po hospitalizacji z powodu HF. Ta ostatnia grupa jest obciążona o wiele gorszym rokowaniem.

Śmiertelność pacjentów hospitalizowanych z powodu HF wynosi nawet 30\% w obserwacji rocznej po zakończeniu hospitalizacji [16], a w okresie 60-90 dni po wypisaniu waha się od $5 \%$ do $15 \%[6,8]$. Aż $28 \%$ pacjentów po pobycie w szpitalu z powodu HF wymaga ponownej hospitalizacji z tej samej przyczyny w pierwszych 30 dniach [17]. W populacji EVEREST $(n=4133)$ było 5239 hospitalizacji u 52,2\% chorych w blisko 10 -miesięcznej obserwacji, w tym $24,1 \%$ hospitalizacji z powodu HF miało miejsce w pierwszych 30 dniach od wypisania mimo optymalnego leczenia i wczesnych wizyt kontrolnych [8]. Z kolei ponownej hospitalizacji z powodu HF w okresie 30-60 dni od wypisania wymagało $19,5 \%$ chorych, a po więcej niż 60 dniach - 56,4\% (ryc. 2). W badaniu EVEREST aż 46,3\% wszystkich hospitalizacji wiązało się z HF [8]. W europejskim rejestrze Euro Heart Survey Pilot ponownie hospitalizowanych w trakcie rocznej obserwacji było $24,75 \%$ pacjentów [18].

Z każdą kolejną hospitalizacją z powodu HF pogarsza się rokowanie, co udowodnili w swoich badaniach Setoguchi i wsp. [19] - mediana przeżycia po pierwszej, drugiej, trzeciej i czwartej hospitalizacji wynosiła odpowiednio 2,4, 1,4, 1,0 i 0,6 roku. Czynników wpływających na rokowanie pacjentów hospitalizowanych z powodu HF jest wiele i poza faktem hospitalizacji należy wymienić między innymi długość okresu hospitalizacji, współistniejącą chorobę wieńcową, niewydolność nerek, niskie skurczowe ciśnienie tętnicze (< $120 \mathrm{~mm} \mathrm{Hg}$ ), dyssynchronię międzykomorową, podwyższenie stężenia troponiny i hiponatremię [20].

W 2010 roku ukazały się wyniki badania SHIFT, w którym udokumentowano obniżenie ryzyka hospitalizacji z powodu HF u pacjentów z wywiadem hospitalizacji z powodu zaostrzenia HF w ciągu ostatnich 12 miesięcy, będących aktualnie w II-IV klasie według NYHA z rytmem zatokowym o częstości co najmniej 70/min i upośledzoną kurczliwością (LVEF < 35\%) [11]. W grupie chorych przyjmujących iwabradynę względne ryzyko hospitalizacji z powodu zaostrzenia HF obniżyło się o 26\% (incidence rate ratio 0,74, 95-proc. przedział ufności [Cl, confidence interval], 0,65-0,87; $p=0,0002)$. Wyniki badania SHIFT zmieniły algorytm postępowania terapeutycznego w przewlekłej HF a iwabradyna znalazła swoje miejsce w wytycznych ESC [3]. Co istotne, w późniejszych analizach badania SHIFT dowiedziono, że lek ten obniżał również ryzyko drugiej (współczynnik ryzyka [HR, hazard ratio] 0,66, 95\% Cl, 0,55-0,79; $<<0,001$ ) i trzeciej hospitalizacji z powodu HF (HR 0,71, 95\% Cl $0,54-0,93 ; p=0,012$ ) (ryc. 3) [21].

W ostatnio opublikowanej pracy Habal i wsp. [22] służącej analizie populacji I i II fazy badania EFFECT-HF (Enhanced Feedback For Effective Cardiac Treatment), do którego włączono 9097 pacjentów z HF i rytmem zatokowym, udowodniono, że ryzyko hospitalizacji z powodu HF w okresie wczesnym pierwszych 30 dni od wypisania było istotnie wyższe w populacji pacjentów z rejestrowaną przy wypisie częstością rytmu serca ponad 90/min (HR 1,26, 95\% Cl 1,04-1,54; $p=0,021)$. Z kolei w analizie post-hoc badania EVEREST (Efficacy of Vasopressin Antagonism

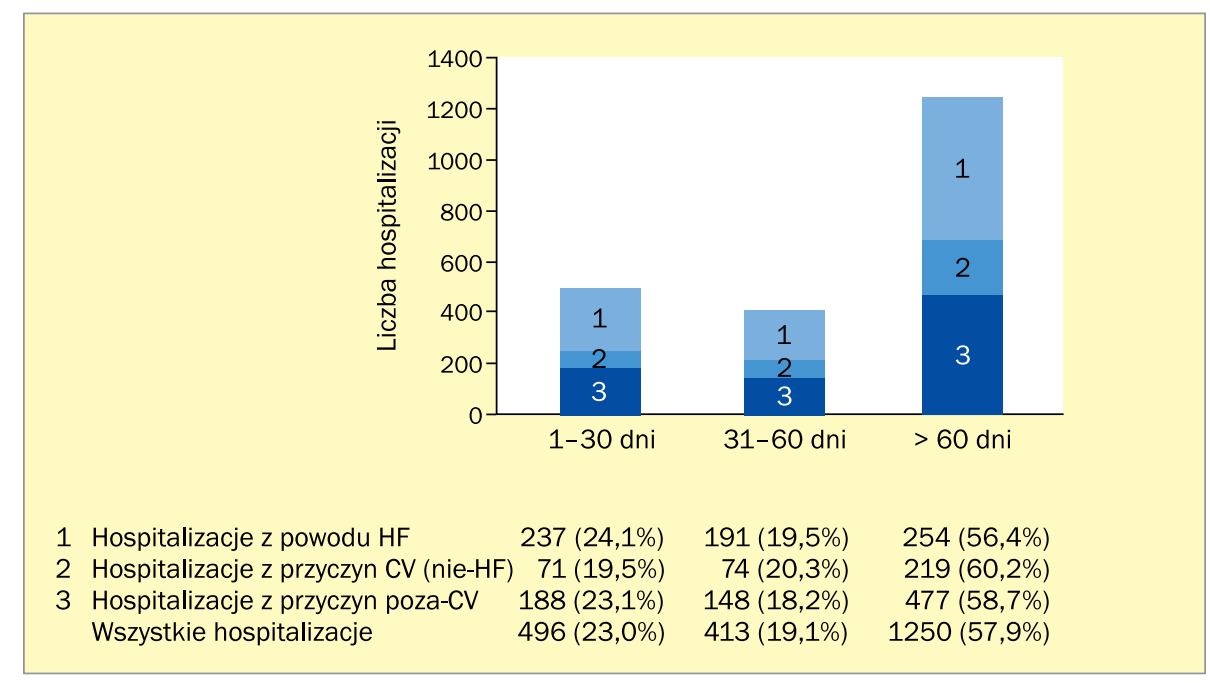

Rycina 2. Hospitalizacje po wypisaniu ze szpitala (do 30 dni, 31-60 dni i > 60 dni) w populacji leczonej z powodu niewydolności serca (zmodyfikowano wg [8]); HF (heart failure) - niewydolność serca; CV (cardiovascular) - sercowo-naczyniowy 


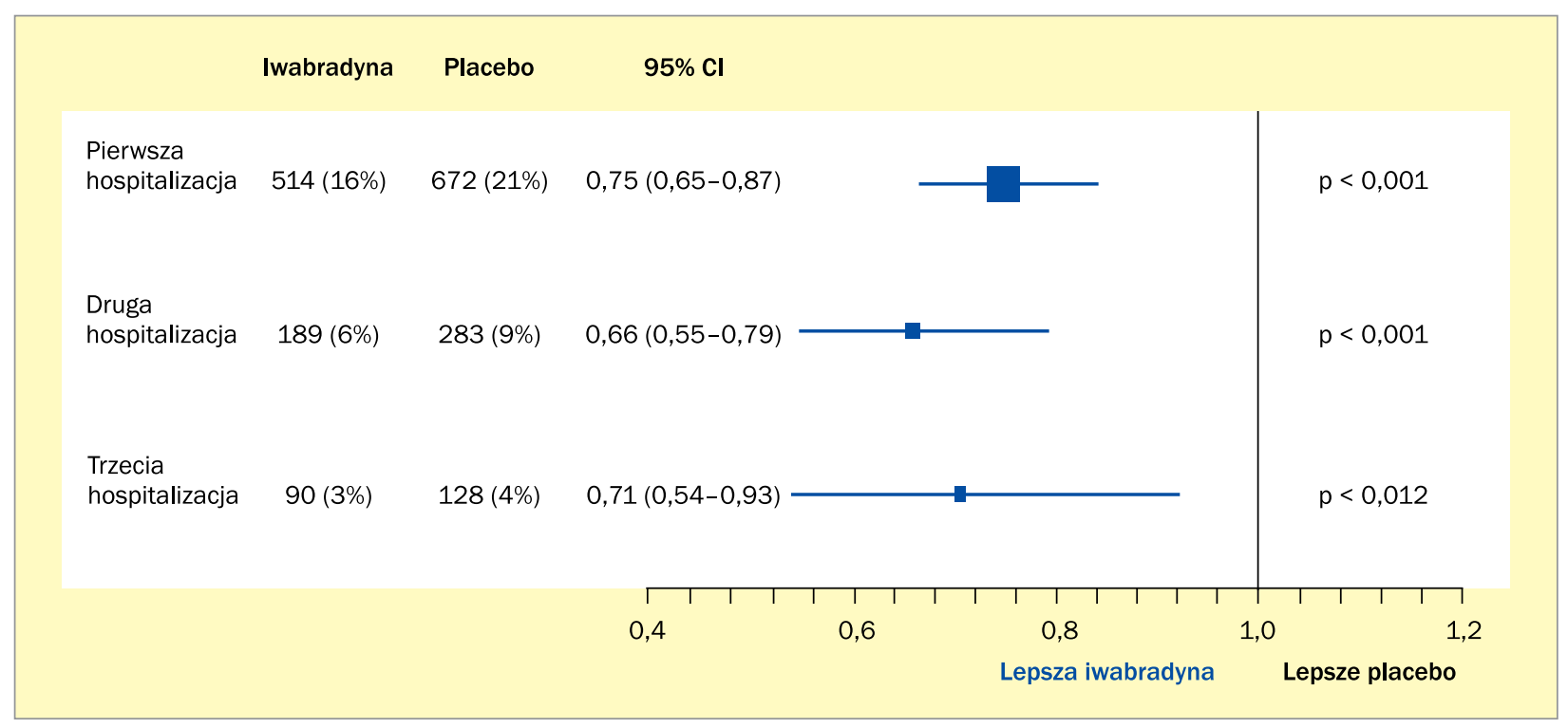

Rycina 3. Obniżenie ryzyka pierwszych i kolejnych hospitalizacji w badaniu SHIFT (zmodyfikowane wg [21]); Cl (confidence interval) - przedział ufności

in Heart Failure: Outcome Study With Tolvaptan), które przeprowadzono w grupie 1947 pacjentów z LVEF poniżej 40\%, z rytmem zatokowym, wykazano, że w grupie osób z częstością rytmu serca ponad 70/min wzrost częstości o każde 5 uderzeń/min wiąże się z wyższym ryzykiem wczesnej (< 100 dni) śmiertelności ogólnej (HR 1,13, 95\% Cl 1,05-1,22; p =0,002) [23]. Z analizy tej pochodzą również cenne wskazówki praktyczne. Autorzy udokumentowali, że częstość rytmu serca ponad 70/min jest istotna rokowniczo nie tylko przy wypisaniu, ale również w ocenie tydzień później oraz 4 tygodnie po zakończeniu hospitalizacji.

\section{Zapobieganie hospitalizacjom w HF jako cel terapeutyczny}

W tabeli 2 zebrano informacje dotyczące farmakoterapii i elektroterapii zalecanych w celu ograniczenia hospitalizacji w HF. Inhibitory ACE obniżają względne ryzyko hospitalizacji z powodu HF o $26 \%$, beta-adrenolityki - o 28-36\%, MRA - o 35\%, ARB - o 17-24\%, iwabradyna - o 26\% (badanie SHIFT), a digoksyna - o 28\% [3], natomiast terapia resynchronizująca - od $25 \%$ do nawet $53 \%$ (w porównaniu z ICD) [24].

W tabeli 3 przedstawiono zmienne prognostyczne przy wypisaniu ze szpitala oraz we wczesnym okresie po wypisaniu [25]. Znanych jest wiele czynników prognostycznych wystapienia hospitalizacji w HF, które zbiorczo przedstawiono w artykule opublikowanym w czasopiśmie „Kardiologia po Dyplomie" [26]. Główną przyczyną wczesnej readmisji pacjentów z HF jest retencja płynów objawiająca się obrzękami obwodowymi i zastojem w krążeniu płucnym oraz niski rzut serca [27]. Z praktycznego punktu widzenia szczególnie istotne są te dane kliniczne, które wskazują na podwyższone ryzyko wczesnej rehospitalizacji i powinny być ocenione przy wypisaniu ze szpitala. Należą do nich [25, 28]:

- subkliniczna retencja płynów (podwyższenie ciśnienia napełniania lewej komory, co często odzwierciedla wysokie stężenie peptydów natriuretycznych);

- zwiększenie masy ciała;

- pogorszenie czynności nerek oraz

- częstość rytmu serca [22].

Ograniczenie sodu pozostaje fundamentem gospodarki płynowej, natomiast diuretyki pętlowe są podstawą leczenia farmakologicznego w przypadku retencji płynów. Różnice między dostępnymi na polskim rynku diuretykami pętlowymi - furosemidem i torasemidem - takie jak biodostępność, czas i siła działania oraz działania niepożądane, mają niezwykle istotne znaczenie kliniczne. W świetle wielu badań klinicznych torasemid jest dobra alternatywą dla powszechnie stosowanego furosemidu u chorych z przewlekłą HF. Szersze stosowanie torasemidu cechującego się lepszymi właściwościami farmakologicznymi, silniejszym i dłuższym działaniem z udokumentowanym zmniejszeniem śmiertelności [29] jest bardziej uzasadnione z klinicznego oraz ekonomicznego punktu widzenia. Lepsze wyniki leczenia, uzyskiwane $w$ trakcie terapii torasemidem, mogą skrócić czas hospitalizacji. Fakt ten jest niezmiernie istotny nie tylko z punktu widzenia pacjentów, krócej przebywających w placówkach opieki zdrowotnej, ale również od strony systemowej - dla szpitali. Możliwość szybszej optymalizacji stanu chorego obniża bowiem istotnie koszty hospitalizacji. 
Tabela 2. Farmakoterapia i elektroterapia w celu zmniejszenia ryzyka hospitalizacji z powodu niewydolności serca (HF, heart failure) (źródła $[3,24])$

\begin{tabular}{|c|c|c|c|c|}
\hline Terapia & Cel & Warunki zastosowania & Klasa & $\begin{array}{l}\text { Poziom } \\
\text { zaleceń }\end{array}$ \\
\hline Beta-adrenolityk & $\begin{array}{l}\text { W celu obniżenia ryzyka hospita- } \\
\text { lizacji z powodu HF oraz ryzyka } \\
\text { przedwczesnego zgonu }\end{array}$ & LVEF $<40 \%$ & 1 & A \\
\hline $\begin{array}{l}\text { Inhibitor konwertazy an- } \\
\text { giotensyny (ACE) }\end{array}$ & $\begin{array}{l}\text { W celu obniżenia ryzyka hospita- } \\
\text { lizacji z powodu HF oraz ryzyka } \\
\text { przedwczesnego zgonu }\end{array}$ & LVEF $<40 \%$ & I & A \\
\hline $\begin{array}{l}\text { Antagonista receptora } \\
\text { mineralokortykoidowego } \\
\text { (MRA) }\end{array}$ & $\begin{array}{l}\text { W celu obniżenia ryzyka hospita- } \\
\text { lizacji z powodu HF oraz ryzyka } \\
\text { przedwczesnego zgonu }\end{array}$ & $\begin{array}{l}\text { II-IV klasa wg NYHA, mimo beta-adrenoli- } \\
\text { tyku i inhibitora ACE oraz LVEF }<35 \%\end{array}$ & 1 & A \\
\hline $\begin{array}{l}\text { Antagonista receptora } \\
\text { angiotensynowego (ARB) }\end{array}$ & $\begin{array}{l}\text { W celu obniżenia ryzyka hospitali- } \\
\text { zacji oraz ryzyka przedwczesnego } \\
\text { zgonu }\end{array}$ & $\begin{array}{l}\text { Przy nietolerancji inhibitora ACE } \\
\text { i LVEF }<40 \%\end{array}$ & 1 & A \\
\hline \multirow[t]{2}{*}{ Iwabradyna } & $\begin{array}{l}\text { W celu obniżenia ryzyka hospita- } \\
\text { lizacji }\end{array}$ & $\begin{array}{l}\mathrm{RS}, \mathrm{LVEF}<35 \%, \mathrm{HR} \geq 70 / \mathrm{min} \text { i NYHA II-IV } \\
\text { mimo beta-adrenolityku, inhibitor ACE } \\
\text { i MRA w zalecanych dawkach }\end{array}$ & Ila & B \\
\hline & $\begin{array}{l}\text { W celu obniżenia ryzyka hospita- } \\
\text { lizacji }\end{array}$ & $\begin{array}{l}\text { Nietolerancja beta-adrenolityku, RS, LVEF } \\
<35 \%, H R \geq 70 / \text { min, inhibitor ACE i MRA } \\
\text { w zalecanych dawkach }\end{array}$ & $\mathrm{llb}$ & C \\
\hline \multirow[t]{2}{*}{ Digoksyna } & $\begin{array}{l}\text { W celu obniżenia ryzyka hospita- } \\
\text { lizacji }\end{array}$ & $\begin{array}{l}\text { Nietolerancja beta-adrenolityku, RS, LVEF } \\
<45 \% \text {, inhibitor ACE i MRA w zalecanych } \\
\text { dawkach }\end{array}$ & $\mathrm{llb}$ & B \\
\hline & $\begin{array}{l}\text { W celu obniżenia ryzyka hospita- } \\
\text { lizacji }\end{array}$ & $\begin{array}{l}\text { LVEF }<35 \%, \text { HR } \geq 70 / \text { min i II-IV klasa } \\
\text { wg NYHA, mimo beta-adrenolityku, inhibi- } \\
\text { tor ACE i MRA w zalecanych dawkach }\end{array}$ & $\mathrm{llb}$ & B \\
\hline \multirow[t]{2}{*}{$\begin{array}{l}\text { Hydralazyna i diazotan } \\
\text { izosorbidu }\end{array}$} & $\begin{array}{l}\text { W celu obniżenia ryzyka hospitali- } \\
\text { zacji oraz ryzyka przedwczesnego } \\
\text { zgonu }\end{array}$ & $\begin{array}{l}\text { Nietolerancja inhibitora ACE i ARB, } \\
\text { LVEF }<35 \% \text { lub LVEF }<45 \% \text { i rozstrzeń LV }\end{array}$ & $\mathrm{Ilb}$ & B \\
\hline & $\begin{array}{l}\text { W celu obniżenia ryzyka hospitali- } \\
\text { zacji oraz ryzyka przedwczesnego } \\
\text { zgonu }\end{array}$ & $\begin{array}{l}\text { LVEF < 35\% lub LVEF < 45\% i rozstrzeń } \\
\text { LV, II-IV klasa wg NYHA mimo beta-adre- } \\
\text { nolityku, inhibitor ACE i MRA w zalecanych } \\
\text { dawkach }\end{array}$ & IIb & B \\
\hline n-3 PUFA & $\begin{array}{l}\text { W celu obniżenia ryzyka hospitali- } \\
\text { zacji oraz ryzyka przedwczesnego } \\
\text { zgonu }\end{array}$ & $\begin{array}{l}\text { Beta-adrenolityk, inhibitor ACE i MRA } \\
\text { w zalecanych dawkach }\end{array}$ & $\mathrm{llb}$ & B \\
\hline \multirow[t]{4}{*}{ CRT-P/CRT-D } & $\begin{array}{l}\text { W celu obniżenia ryzyka hospitali- } \\
\text { zacji oraz ryzyka śmiertelności }\end{array}$ & $\begin{array}{l}\text { LBBB, QRS > } 150 \text { ms, II-IV klasa } \\
\text { wg NYHA, RS, LVEF < 35\% }\end{array}$ & I & $A$ \\
\hline & $\begin{array}{l}\text { W celu obniżenia ryzyka hospitali- } \\
\text { zacji oraz ryzyka śmiertelności }\end{array}$ & $\begin{array}{l}\text { LBBB, QRS } 120-150 \text { ms, II-IV klasa } \\
\text { wg NYHA, RS, LVEF < 35\% }\end{array}$ & 1 & B \\
\hline & $\begin{array}{l}\text { W celu obniżenia ryzyka hospitali- } \\
\text { zacji oraz ryzyka śmiertelności }\end{array}$ & $\begin{array}{l}\text { Nie-LBBB, QRS > } 150 \text { ms, II-IV klasa } \\
\text { wg NYHA, RS, LVEF < 30\% }\end{array}$ & Ila & B \\
\hline & $\begin{array}{l}\text { W celu obniżenia ryzyka hospitali- } \\
\text { zacji oraz ryzyka śmiertelności }\end{array}$ & $\begin{array}{l}\text { Nie-LBBB, QRS } 120-150 \mathrm{~ms} \text {, II-IV kla- } \\
\text { sa wg NYHA, RS, LVEF < 35\% }\end{array}$ & $\mathrm{Ilb}$ & B \\
\hline
\end{tabular}


Tabela 3. Ocena zmiennych prognostycznych w chwili wypisania oraz we wczesnym okresie po wypisaniu ze szpitala (źródło [25])

\begin{tabular}{|c|c|c|c|}
\hline & Zapobieganie przeładowaniu płynami & Zmniejszenie objawów & Poprawa rokowania \\
\hline \multicolumn{4}{|l|}{ Parametry kliniczne } \\
\hline Objawy zastoju & +++ & + & ++ \\
\hline Ciśnienie tętnicze & + & $?$ & + \\
\hline Częstość rytmu serca & $?$ & + & + \\
\hline Test ortostatyczny & + & $?$ & ? \\
\hline \multicolumn{4}{|l|}{ Badanie elektrokardiograficzne } \\
\hline Czas QRS (w kontekście CRT) & + & ++ & +++ \\
\hline $\mathrm{AF} /$ tachyarytmie & $+?$ & + & ++ \\
\hline \multicolumn{4}{|l|}{ Badania laboratoryjne } \\
\hline Żywotność mięśnia sercowego & + & + & $++(?)$ \\
\hline Peptydy natriuretyczne & ++ & + & + \\
\hline Czynność nerek/elektrolity & + & $+/ 0$ & $+/++(?)$ \\
\hline Niedokrwistość/niedobór żelaza & ? & ++ & + \\
\hline
\end{tabular}

Podsumowując, w odniesieniu do pacjenta z HF obowiązują następujące cele leczenia w fazie „okołowypisowej” [3]:

- utrzymanie stabilnego stanu pacjenta;

- rozpoczęcie, intensyfikowanie i optymalizacja farmakoterapii modyfikującej przebieg choroby;

- rozważenie leczenia z zastosowaniem urządzeń wszczepialnych;

- identyfikacja pacjentów z grup podwyższonego ryzyka i ocena statusu nawodnienia;

- ustalenie etiologii HF oraz istotnych chorób współistniejących;

- kwalifikacja do programu kompleksowego leczenia HF, edukacja, wprowadzenie odpowiedniej korekty stylu życia.

Komplementarne postępowanie przedłużające życie w HF i ograniczające hospitalizacje z powodu tej choroby przedstawiono na rycinie $4[30,31]$. W celi poprawy opieki nad pacjentem z HF w 2014 roku Sekcja Niewydolności Serca Polskiego Towarzystwa Kardiologicznego opracowała „Paszport pacjenta z niewydolnością serca”. Paszport jest przeznaczony nie tylko dla pacjentów, ale również dla wszystkich lekarzy, do których trafia chory z HF, a więc lekarzy rodzinnych, internistów, geriatrów i kardiologów. Dokument jest dostępny w wersji elektronicznej na stronie internetowej http://www.ptkardio.pl/ /Paszport_pacjenta_z_niewydolnoscia_serca_br_i_Pobierz_pomoc_dla_pacjentow_i_-2318.

\section{Nowe leczenie HF}

We wrześniu 2014 roku na kongresie ESC w Barcelonie ogłoszono wyniki przełomowego badania PARADIGM-HF (Prospective comparison of ARNI with angiotensin convering-enzyme inhibitors to determine impact on global mortality and morbidity in heart failure trial) - wieloośrodkowego, randomizowanego badania klinicznego III fazy, przeprowadzonego metodą podwójnie ślepej próby, służącego ocenie długoterminowej skuteczności i bezpieczeństwa terapii za pomocą LCZ696 w porównaniu z enalaprilem w grupie 8442 pacjentów z przewlekłą objawową HF i obniżoną LVEF poniżej 40\%, poddanych pełnemu, tolerowanemu, zgodnemu z aktualnymi zaleceniami leczeniu HF [15]. LCZ696 jest pierwszym lekiem z grupy inhibitorów receptora angiotensyny i neprylizyny (ARNI, angiotensin receptor neprilysin inhibitor). Zawiera inhibitor neprylizyny (sacubitryl) oraz ARB (walsartan). Neprylizyna jest enzymem proteolitycznym z grupy metaloproteaz, rozkłada i unieczynnia między innymi peptydy natriuretyczne (peptyd natriuretyczny typu A [ANP, A-type natriuretic peptide], peptyd natriuretyczny typu B [BNP, B-type natriuretic peptide]), bradykininę, adrenomedulinę. Hamowanie neprylizyny prowadzi do zwiększenia dostępności peptydów natriuretycznych, które wykazują korzystny wpływ na układ sercowo-naczyniowy w HF - zwiększają natriurezę oraz diureze, działają naczyniorozszerzająco oraz hamują niekorzystny remodeling mięśnia sercowego [32].

Na podstawie wyników badania PARADIGM-HF z medianą obserwacji 27 miesięcy wiadomo, że terapia LCZ696 w porównaniu z leczeniem enalaprilem wiązała się z [15]:

- redukcją o 20\% pierwszorzędowego punktu końcowego, na który składały się zgon z przyczyn sercowo-naczyniowych lub hospitalizacja z powodu HF (21,8\% v. 26,5\%; HR 0,80; 95\% Cl 0,73-0,87; p < 0,001);

- redukcją ryzyka zgonu z przyczyn sercowo-naczyniowych o $20 \%$ (13,3\% v. 16,5\%; HR 0,80, 95\% Cl 0,71-0,89; $\mathrm{p}<0,001)$ oraz 


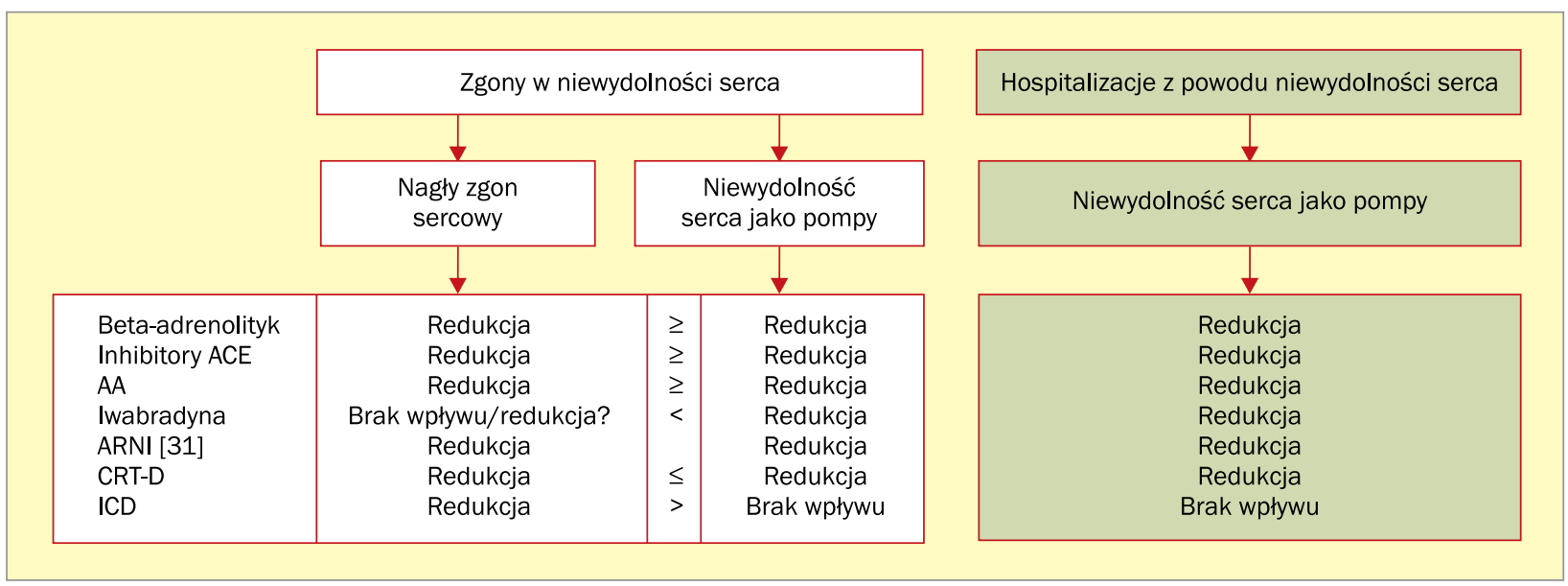

Rycina 4. Komplementarne postępowanie przedłużające życie w niewydolności serca i ograniczające hospitalizacje z jej powodu (zmodyfikowano wg [30]); ACE (angiotensin-converting enzyme) - enzym konwertujący angiotensynę; AA (aldosterone antagonist) - antagonista aldosteronu; ARNI (angiotensin receptor neprilysin inhibitor) - bloker receptora angiotensyny i inhibitora neprylizyny; CRT-D (cardiac resynchronization therapy with defibrillator function) - terapia resynchronizująca z funkcją defibrylacji; ICD (implantable cardioverter-defibrillator) - wszczepialny kardiowerter-defibrylator

- obniżeniem ryzyka hospitalizacji z powodu HF o $21 \%$ (12,8\% v. 15,6\%; HR 0,79, 95\% Cl 0,71-0,89; $\mathrm{p}<0,001)$.

Ponadto na podstawie pośredniej analizy LCZ696 z PARADIGM-HF, w porównaniu z domniemanym efektem placebo z badań SOLVD-T i CHARM-Alternative, wykazano, że LCZ696 w porównaniu z placebo powinno obniżać ryzyko zgonu z przyczyn sercowo-naczyniowych o 32-34\% ( $p<0,001$ ), ryzyko hospitalizacji z powodu HF - o 46-49\% ( $p<0,0001)$, a ryzyko śmiertelności całkowitej - o 26-28\% $(p<0,005)$ [33]. Można zatem oczekiwać, że w najbliższych wytycznych dotyczących postępowania u chorych z przewlekłą HF LCZ696 (obecna nazwa: sacubitril/walsartan) stanie się lekiem zalecanym w pierwszej linii farmakoterapii pacjentów z HF i obniżoną LVEF.
Podsumowując, przewiduje się, że za 20 lat koszty związane z leczeniem HF wzrosną nawet o 200 proc., co będzie następstwem starzenia się polskiego społeczeństwa. Zatem pełna implementacja wytycznych terapii HF z wczesnym ukierunkowaniem na pump failure, nowe możliwości leczenia z modulacją szlaków neurohormonalnych przez leki z grupy ARNI oraz poprawa ambulatoryjnego systemu opieki nad pacjentem z HF mogą się przyczynić do zwiększenia efektywności terapii, co powinno się przełożyć na zmniejszenie częstości hospitalizacji, poprawę rokowania i wymierne korzyści ekonomiczne.

\section{Konflikt interesów}

Udział w badaniu PARAGON-HF.

\section{Abstract}

Progress in therapy, mainly in electrotherapy, has increased life expectancy in patients with heart failure (HF). Disease progression despite treatment leads to advanced HF, with pump failure as its dominant manifestation. This is related to increased rate of hospitalization for HF. Therefore, early introduction of appropriate therapy is necessary to reduce rehospitalization due to worsening of HF.

Key words: heart failure, treatment, rehospitalization

Folia Cardiologica 2016; 11, 1: 37-46 


\section{Piśmiennictwo}

1. Gierczyński J., Gryglewicz J., Karczewicz E., Zalewska H. Niewydolność serca - analiza kosztów ekonomicznych i społecznych. Uczelnia Łazarskiego, Warszawa 2013.

2. Heidenreich P.A., Albert N.M., Allen L.A. i wsp. Forecasting the impact of heart failure in the United States: a policy statement from the American Heart Association. Circ. Heart Fail. 2013; 6: 606-619.

3. McMurray J.J., Adamopoulos S., Anker S.D. i wsp. ESC Guidelines for the diagnosis and treatment of acute and chronic heart failure 2012: the Task Force for the Diagnosis and Treatment of Acute and Chronic Heart Failure 2012 of the European Society of Cardiology. Developed in collaboration with the Heart Failure Association (HFA) of the ESC. Eur. Heart J. 2012; 33: 1787-1847.

4. OECD 2015 Avoidable hospital admissions in Health AT a Glance 2015: OECD Indicators, OECD Publishing, Paris.

5. Loh J.C., Creaser J., Rourke D.A. i wsp. Temporal trends in treatment and outcomes for advanced heart failure with reduced ejection fraction from 1993-2010: findings from a university referral center. Circ. Heart Fail. 2013; 6: 411-419.

6. Fonarow G.C., Stough W.G., Abraham W.T. i wsp. Characteristics, treatments, and outcomes of patients with preserved systolic function hospitalized for heart failure: a report from the OPTIMIZE-HF registry. J. Am. Coll. Cardiol. 2007; 50: 768-777.

7. Filippatos G., Rossi J., Lloyd-Jones D.M. i wsp. Prognostic value of blood urea nitrogen in patients hospitalized with worsening heart failure: insights from the Acute and Chronic Therapeutic Impact of a Vasopressin Antagonist in Chronic Heart Failure (ACTIV in CHF). J. Card. Fail. 2007; 13: 360-364.

8. O'Connor C.M., Miller A.B., Blair J.E. i wsp. Causes of death and rehospitalization in patients hospitalized with worsening heart failure and reduced left ventricular ejection fraction: results from Efficacy of Vasopressin Antagonism in Heart Failure Outcome Study with Tolvaptan (EVEREST) program. Am. Heart J. 2010; 159: 841-849.

9. Klein L., Massie B.M., Leimberger J.D. i wsp. Admission or changes in renal function during hospitalization for worsening heart failure predict postdischarge survival: results from the Outcomes of a Prospective Trial of Intravenous Milrinone for Exacerbations of Chronic Heart Failure (OPTIME-CHF). Circ. Heart Fail. 2008; 1: 25-33.

10. Gheorghiade M., Rossi J.S., Cotts W. i wsp. Characterization and prognostic value of persistent hyponatremia in patients with severe heart failure in the ESCAPE Trial. Arch. Intern. Med. 2007; 167: 1998-2005.

11. Swedberg K., Komajda M., Böhm M. i wsp. Ivabradine and outcomes in chronic heart failure (SHIFT): a randomized placebo-controlled study. Lancet 2010; 376: 875-885.

12. Bristow M.R., Saxon L.A., Boehmer J. i wsp. Cardiac-resynchronization therapy with or without an implantable defibrillator in advanced chronic heart failure. N. Engl. J. Med. 2004; 350: 2140-2150.

13. Moss A.J., Hall W.J., Cannom D.S. i wsp. Cardiac-resynchronization therapy for the prevention of heart failure events. N. Engl. J. Med. 2009; 361: 1329-3138.

14. Tang A.S., Wells G.A., Talajic M. i wsp. Cardiac-resynchronization therapy for mild-to-moderate heart failure. N. Engl. J. Med. 2010; 363: 2385-2395.

15. McMurray J.J., Packer M., Desai A.S. i wsp. Angiotensin-neprilysin inhibition versus enalapril in heart failure. N. Engl. J. Med. 2014; 371: 993-1004.

16. Chen J., Normand S.L., Wang Y., Krumholz H.M. National and regional trends in heart failure hospitalization and mortality rates for Medicare beneficiaries, 1998-2008. JAMA 2011; 306: 1669-1678.

17. Epstein A.M., Jha A.K., Orav E.J. The relationship between hospital admission rates and rehospitalizations. N. Engl. J. Med. 2011; 365: 2287-2295.
18. Maggioni A.P., Dahlström U., Filippatos G. i wsp. EURObservational Research Programme: regional differences and 1-year follow-up results of the Heart Failure Pilot Survey (ESC-HF Pilot). Eur. J. Heart Fail. 2013; 15: 808-817.

19. Setoguchi S., Stevenson L.W., Schneeweiss S. Repeated hospitalizations predict mortality in the community population with heart failure. Am. Heart J. 2007; 154: 260-266.

20. Gheorghiade M., Vaduganathan M., Fonarow G.C., Bonow R.O. Rehospitalization for heart failure: problems and perspectives. J. Am. Coll. Cardiol. 2013; 61: 391-403.

21. Borer J.S., Bohm M., Ford I. i wsp. Effect of ivabradine on recurrent hospitalization for worsening heart failure in patients with chronic systolic heart failure: the SHIFT study. Eur. Heart J. 2012; 33: $2813-$ $-2820$.

22. Habal M.V., Liu P.P., Austin P.C. i wsp. Association of heart rate at hospital discharge with mortality and hospitalizations in patients with heart failure. Circ. Heart Fail. 2014; 7: 12-20.

23. Greene S.J., Vaduganathan M., Wilcox J.E. i wsp. The prognostic significance of heart rate in patients hospitalized for heart failure with reduced ejection fraction in sinus rhythm: insights from the EVEREST (Efficacy of Vasopressin Antagonism in Heart Failure: Outcome Study With Tolvaptan) trial. JACC Heart Fail. 2013; 1: 488-496.

24. Brignole M., Auricchio A., Baron-Esquivias G. i wsp. 2013 ESC Guidelines on cardiac pacing and cardiac resynchronization therapy: the Task Force on cardiac pacing and resynchronization therapy of the European Society of Cardiology (ESC). Developed in collaboration with the European Heart Rhythm Association (EHRA). Eur. Heart J. 2013; 34: 2281-2329.

25. Metra M., Gheorghiade M., Bonow R.O., Dei Cas L. Postdischarge assessment after a heart failure hospitalization: the next step forward. Circulation 2010; 122: 1782-1785.

26. Wojtczak-Soska K., Lelonek M. Ponowne hospitalizacje w niewydolności serca. Kard. Dypl. 2014; 13: 14-21.

27. Zaya M., Phan A., Schwarz E.R. Predictors of re-hospitalization in patients with chronic heart failure. World J. Cardiol. 2012; 4: 23-30.

28. Gheorghiade M., Pang P.S., Ambrosy A.P. i wsp. A comprehensive, longitudinal description of the in-hospital and post-discharge clinical, laboratory, and neurohormonal course of patients with heart failure who die or are re-hospitalized within 90 days: analysis from the EVEREST trial. Heart Fail. Rev. 2012; 17: 485-509.

29. Cosín J., Díez J.; TORIC investigators. Torasemide in chronic heart faiIure: results of the TORIC study. Eur. J. Heart Fail. 2002; 4: 507-513.

30. Filipiak K., Szymański F.M. Krytyczne spojrzenie na dostępne metody leczenia niewydolności serca: Anno Domini 2014. Kardiol. Pol. 2014; 72 (supl. I): 1-9.

31. Desai A.S., McMurray J., Packer M. i wsp. Effect of the angiotensin-receptor-neprilysin inhibitor LCZ696 compared with enalapril on mode of death in heart failure patients. Eur. Heart J. 2015; 36: 1990-1997.

32. McMurray J.J., Packer M., Desai A.S. i wsp. Dual angiotensin receptor and neprilysin inhibition as an alternative to angiotensin-converting enzyme inhibition in patients with chronic systolic heart failure: rationale for and design of the Prospective comparison of ARNI with ACEI to Determine Impact on Global Mortality and morbidity in Heart Failure trial (PARADIGM-HF). Eur. J. Heart Fail. 2013; 15: 1062-1073.

33. McMurray J.J., Packer M., Desai A. i wsp. A putative placebo analysis of the effects of LCZ696 on clinical outcomes in heart failure. Eur. Heart J. 2015; 36: 434-439. 